\title{
Effects of dietary conjugated linoleic acid on growth and body composition of control and IGF-I transgenic pigs 1
}

\author{
Alva D. MitChELl ${ }^{a} *$, Vernon G. PURSEL ${ }^{a}$, Theodore H. ElSASSER ${ }^{\mathrm{a}}$, \\ John P. MCMURTRY ${ }^{\mathrm{a}}$, Giuseppe BEE ${ }^{\mathrm{b}}$ \\ ${ }^{a}$ USDA, Agricultural Research Service, Beltsville, MD 20705, USA \\ b Agroscope Liebefeld-Posieux, Swiss Federal Research Station for Animal Production and Dairy \\ Products (ALP), Posieux, 1725, Switzerland
}

(Received 4 October 2004; accepted 26 May 2005)

\begin{abstract}
Both dietary conjugated linoleic acid (CLA) and presence of the IGF-I transgene are reported to alter the fat:lean content of pigs. The purpose of this study was to compare the growth and body composition of control and IGF-I transgenic pigs in response to dietary CLA. Transgenic (TG) pigs expressing the IGF-I gene and sibling control (C) progeny were produced by mating two half-sib G-1 transgenic boars to non-transgenic gilts. At $60 \mathrm{~kg}$ each pig was scanned by dual-energy X-ray absorptiometry (DXA) for body composition analysis, then placed on an $18 \%$ crude protein diet containing either $2 \%$ corn oil (CO diet) or $1.2 \% \mathrm{CO}$ plus $0.8 \% \mathrm{CLA}$. Thus, the four genotypediet combinations were: C-CO $(n=25)$, C-CLA $(n=25)$, TG-CO $(n=24)$, and TG-CLA $(n=23)$. Each pig was scanned again at $110 \mathrm{~kg}$. All pigs were slaughtered at $120 \mathrm{~kg}$ and the right half-carcass was scanned by DXA. Results of the DXA scan at $60 \mathrm{~kg}$ revealed that the TG pigs were less fat $(15.0 \%)$ than the $\mathrm{C}$ pigs $(18.8 \%, P<0.05)$. During growth from 60 to $110 \mathrm{~kg}$, the tissue gain for the $\mathrm{C}-\mathrm{CO}$, C-CLA, TG-CO, and TG-CLA groups consisted of 16.6, 14.5, 13.2, and $13.0 \mathrm{~kg}$ of fat $(P<0.05$, $\mathrm{C}-\mathrm{CO}$ vs. C-CLA and C vs. TG); and $30.6,32.6,33.7$, and $33.8 \mathrm{~kg}$ of lean $(P<0.05, \mathrm{C}-\mathrm{CO}$ vs. C-CLA and C vs. TG), respectively. There were only minor differences in bone growth. For the same groups, chemical analysis of the half-carcass revealed $29.2,27.1,23.8$, and $22.8 \%$ fat $(P<0.05$ for C-CO vs. C-CLA and C vs. TG), respectively. Overall, the effects of CLA were less than those of TG on body or carcass composition; however, during the treatment period from 60 to $110 \mathrm{~kg}$, the effects were similar. TG pigs did not respond to CLA as much as did control pigs.
\end{abstract}

pig / CLA / IGF-I transgene / body composition

Résumé - Effets de l'acide linoléique conjugué sur la croissance et la composition corporelle de porcs normaux et transgéniques IGF-I. L'acide linoléique conjugué (CLA) et la présence du

\footnotetext{
* Corresponding author: mitchell@anri.barc.usda.gov

${ }^{1}$ Mention of a trade name does not constitute a guarantee or warranty by the USDA and does not imply its approval to the exclusion of other products that may be suitable.
} 
transgène IGF-I ont tous deux des effets sur la composition corporelle du porc. L'objectif de cette étude était de comparer la croissance et la composition corporelle de porcs normaux et transgéniques IGF-I recevant dans leur ration du CLA. Des porcs transgéniques exprimant le gène IGF-I (TG) et des porcs témoins $(\mathrm{C})$ ont été produits en croisant 2 verrats transgéniques de la même famille avec des truies normales. A $60 \mathrm{~kg}$, chaque porc a été scanné par absorptiométrie biphotonique à rayons $\mathrm{X}$ (dual-energy X-ray absorptiometry, DXA) et a reçu une ration avec $18 \%$ de matières azotées, contenant soit $2,0 \%$ d'huile de maîs (CO), soit $1,2 \%$ d'huile de maïs et $0,8 \%$ de CLA. Ainsi 4 combinaisons génotypes $\times$ rations ont été obtenues : $C-C O(n=25), C-C L A(n=25), T G-C O(n=24)$ et TG-CLA $(\mathrm{n}=23)$. Chaque porc a été de nouveau scanné à $110 \mathrm{~kg}$. Tous ont été abattus à $120 \mathrm{~kg}$ et leur demi-carcasse droite scannée et analysée chimiquement. Les résultats de la scanographie faite à $60 \mathrm{~kg}$ montrent que les porcs TG avaient une teneur moindre en gras $(15,0 \%)$ que les porcs $\mathrm{C}$ $(18,8 \%, P<0,05)$. Durant la période de croissance de 60 à $110 \mathrm{~kg}$, le gain tissulaire des groupes C-CO, C-CLA, TG-CO et TG-CLA se composait de $16,6,14,5,13,2$ et $13,0 \mathrm{~kg}$ de gras $(P<0,05$, $\mathrm{C}-\mathrm{CO}$ vs. C-CLA et $\mathrm{C}$ vs. TG) et $30,6,32,6,33,7$ et $33,8 \mathrm{~kg}$ de viande maigre $(P<0,05, \mathrm{C}$-CO vs. C-CLA et C vs. TG), respectivement. La croissance osseuse n'a montré que de faibles variations. Pour les mêmes groupes, la teneur en gras de la demi-carcasse, mesurée par analyse chimique, était de 29,2, 27,1, 23,8 et 22,8 \% ( $P<0,05, \mathrm{C}-\mathrm{CO}$ vs. C-CLA et $\mathrm{C}$ vs. TG) respectivement. D'une manière générale, les effets du CLA ont été moins prononcés sur la composition corporelle et sur la carcasse que ceux dus à la présence du transgène IGF-I, mais ils ont été semblables durant la période expérimentale de 60 à $110 \mathrm{~kg}$. Les porcs TG ont été moins sensibles à l'apport de CLA que les porcs témoins.

porc / CLA / transgène IGF-I / composition corporelle

\section{INTRODUCTION}

Numerous studies have been conducted to evaluate the potential of CLA (CLA, a mixture of positional and geometric conjugated diene isomers of octadecanoic acid) for improving growth performance and carcass composition of swine. Most of these studies have found that the addition of CLA to the diet results in some measure of fat reduction, however results have been inconsistent with regard to growth performance [4]. Supplementation of swine diets with CLA has been shown to decrease fat and increase lean tissue deposition $[3,5,6,19$, 20, 27-30]. While several studies reported that CLA increased the gain:feed ratio $[5,6$, $19,20,28-30]$, only one reported an increase in daily gain [26]. Most of these studies relied on end point measures based on carcass dissection or linear measures of backfat and loin eye area. In order to measure the changes in composition during the period of CLA supplementation, Ostrowska et al. [18] used comparative slaughter to determine body composition at the beginning and end of the study. Dual energy X-ray absorptiometry (DXA) offers an alternative to comparative slaughter for measuring changes in body composition in the live animal. DXA has been shown to be useful for evaluating the composition of both the live pig [7, 12-16, 18, 20, 25, 26] and the pork carcass $[17,24]$. Using DXA, Ostrowska et al. [20] measured the temporal and dose-dependent effects of CLA on body composition of pigs.

Little information is available with respect to how diverse genotypes of pigs respond to dietary CLA. Dugan et al. [5] reported that gilts and barrows respond similarly to CLA supplementation. Wiegand et al. [29] found no interaction between the stress-genotype status of pigs and the subsequent effect of CLA on their growth and performance. Pigs expressing the IGF-I transgene have less fat and more lean tissue than their littermate controls [21]. In these pigs, the IGF-I gene is expressed directly in the skeletal muscle and there is no elevation in circulating $\mathrm{GH}$ [21]. In question in the present study was whether or not supplemental CLA would result in a further improvement in body composition (less fat and more lean) in pigs expressing the IGF-I transgene. Therefore, the purpose of this study was to compare the 
growth and body composition of control and IGF-I transgenic pigs in response to dietary CLA during growth from 60 to $110 \mathrm{~kg}$ body weight (BW) using DXA to make live animal and carcass composition measurements.

\section{MATERIALS AND METHODS}

\subsection{Animals and diets}

Transgenic pigs were produced with a fusion gene composed of avian skeletal actin regulatory sequences and the cDNA encoding IGF-I [21]. Transgenic (TG) and sibling control $(\mathrm{C})$ progeny were produced by mating two half-sibling G-1 transgenic boars to non-transgenic gilts. Presence of the IGF-I transgene was established by Southern blot hybridization analysis of DNA from tail biopsies of the G1 progeny taken at birth. At $60 \mathrm{~kg}$, the pigs were placed on diets with a CP content of $182 \mathrm{~g} \cdot \mathrm{kg}^{-1}$, a ME content of $13.8 \mathrm{MJ} \cdot \mathrm{kg}^{-1}$, and supplemented with either corn oil at $20 \mathrm{~g} \cdot \mathrm{kg}^{-1}$ (CO) or CO at $12 \mathrm{~g} \cdot \mathrm{kg}^{-1}$ plus CLA at $8 \mathrm{~g} \cdot \mathrm{kg}^{-1}$ (CLA). A total of 97 pigs were used in two replicates of a $2 \times 2 \times 2$ factorial arrangement, with the respective factors being diet (CO or CLA), genotype (TG or C), and sex (female or barrow). When possible, a nontransgenic control littermate of the same sex was paired with each transgenic pig and the pair was assigned randomly to their respective diet. Thus, the four genotypediet combinations were: C-CO $(n=25)$, C-CLA $(n=25)$, TG-CO $(n=24)$, and TGCLA ( $n=23)$. Distributed among these were 54 gilts and 43 barrows. Total feed intake for the 60 to $110 \mathrm{~kg}$ growth period was measured for each pig individually. The pigs were housed in individual pens and hand-fed daily with the amount of feed offered based on body weight and adjusted each week after the pigs were weighed. The amount fed was $110 \%$ of calculated ad libitum energy intake [1]. The pigs were weighed weekly on an electronic scale $(+0.2 \mathrm{~kg})$ and the amount of feed presented was adjusted
Table I. Ingredient composition (wt-\%, as-fed basis) of diets ${ }^{\mathrm{A}}$.

\begin{tabular}{|c|c|c|}
\hline \multirow[b]{2}{*}{ Item } & \multicolumn{2}{|c|}{ Treatment } \\
\hline & $\mathrm{CO}$ & CLA \\
\hline Corn & 61.80 & 61.80 \\
\hline Soybean meal $(48 \% \mathrm{CP})$ & 18.00 & 18.00 \\
\hline Dry skim milk, non-fat & 12.00 & 12.00 \\
\hline L-Lysine $\mathrm{HCl}$ & 0.25 & 0.25 \\
\hline Sodium monophosphate & 2.50 & 2.50 \\
\hline Calcium carbonate & 2.50 & 2.50 \\
\hline $\mathrm{NaCl}$ & 0.50 & 0.50 \\
\hline Selenium premix ${ }^{B}$ & 0.05 & 0.05 \\
\hline Mineral premix ${ }^{C}$ & 0.20 & 0.20 \\
\hline Vitamin premix ${ }^{\mathrm{D}}$ & 0.20 & 0.20 \\
\hline Corn oil & 2.00 & 1.20 \\
\hline $\begin{array}{l}\text { Conjugated linoleic acid } \\
(75 \%)^{\mathrm{E}}\end{array}$ & 0.00 & 0.80 \\
\hline
\end{tabular}

A Calculated nutrient composition: crude protein 18\%; ME $13.8 \mathrm{MJ}$ per kg; and total lysine $1.2 \%$ (0.87 g per MJ ME).

B Supplied per kg of diet: $100 \mu \mathrm{g}$ selenium as sodium selenite.

${ }^{C}$ Provided the following micronutrients in $\mathrm{mg}$ per $\mathrm{kg}$ complete diet: $100 \mathrm{Mn}, 100 \mathrm{Fe}, 10 \mathrm{Cu}$, $1 \mathrm{Co}, 3 \mathrm{I}$, and $100 \mathrm{Zn}$.

D Supplied per kg complete diet: $4400 \mathrm{IU}$ vitamin A, 800 IU vitamin D, 11 IU vitamin E, $8.8 \mathrm{mg}$ riboflavin, $17.6 \mathrm{mg}$ pantothenic acid, $30.8 \mathrm{mg}$ niacin, $44 \mu \mathrm{g}$ vitamin $\mathrm{B}_{12}$, and $220 \mathrm{mg}$ choline.

${ }^{\mathrm{E}} \mathrm{CLA}$ contained the following (of total fatty acids based on manufacturers GC analysis, Pharmanutrients, Lake Bluff, IL): C16:0 (palmitic acid), 4.4\%; C18:0 (stearic acid), 2.8\%; C18:1 (oleic acid), $15.4 \%$; $\mathrm{C} 18: 2 \mathrm{c} 9, \mathrm{c} 12$ (linoleic acid) $1.8 \%$; and C18:2, conjugated (CLA), consisting of $34.9 \% \mathrm{c} 9, \mathrm{t} 11$ and $35.9 \% \mathrm{t} 10, \mathrm{c} 12$ isomers.

according to body weight. Feed not consumed each day was weighed and discarded. Composition of the experimental diets is shown in Table I. The basal diet used in this study is the same as used in previous studies with this population of IGF-I TG pigs $[21,22]$. The CLA supplement was a free fatty acid oil consisting of an isomeric form of octadecadienoic acid (linoleic acid) containing approximately equal portions of the $\mathrm{c} 9, \mathrm{t} 11$ and $\mathrm{t} 10, \mathrm{c} 12$ isomers. Approximately $75 \%$ of the product was CLA (Tab. I). 
Water was available ad libitum. The experimental protocols used in this research were approved by the Beltsville Area Institutional Animal Care and Use Committee.

\subsection{Live animal measurements}

Each pig was scanned at 60 and again at $110 \mathrm{~kg}$ BW by dual-energy X-ray absorptiometry (DXA) for body composition analysis using a Lunar DPX-L instrument (GELunar, Madison, WI) as described by Mitchell et al. [7]. Pigs were fasted overnight and then anesthetized using a mixture of Ketamine, Tiletamine, Zolazepam, and Zylazine [13] to prevent movement during the scanning procedure. The DXA scans provided measurements of total body fat, lean, bone mineral content (BMC), and bone mineral density (BMD). Total body fat was calculated from the DXA readings using the following equation from Mitchell et al. [15]: Fat $(\%)=493.4+($ DXA R value $\times 348.8)$. Bone content was calculated from DXA bone mineral $(\mathrm{BMC})$ values $($ Bone $(\mathrm{kg})=$ $\mathrm{BMC} \times 4.14$ ) based on the $24.14 \%$ ash content of pork bones reported by Field et al. [10]. Lean content (including internal organs, connective tissue and gut fill) was calculated as: Lean $(\mathrm{kg})=\mathrm{BW}-(\mathrm{Fat}+\mathrm{Bone})$. DXA measurements of bone mineral density (BMD, g per $\mathrm{cm}^{2}$ ) were made for various regions of the body as described by Mitchell et al. [16]. Ultrasound measurements (Aloca Model SSD-500V) of loineye area (LEA) and backfat (BF) depth were made at the level of the 10th rib while the pigs were positioned for scanning on the DXA instrument. Total body fat, lean and bone deposition were based on the differences between the 60 and 110-kg DXA measurements of fat, lean and BMC.

\subsection{Carcass measurements}

All pigs were slaughtered at $122 \pm 3 \mathrm{~kg}$ $\mathrm{BW}($ mean $\pm \mathrm{SD})$ and the right half-carcass was scanned by DXA [17]. DXA measurements of fat content were adjusted using the following formulas: TOTAL CARCASS \%
FAT $=450-(315 \times \mathrm{R}$ value $) ;$ SHOULDER $\%$ FAT $=390-(269 \times \mathrm{R}$ value $) ;$ HAM $\%$ FAT $=356-(245 \times \mathrm{R}$ value $) ;$ LOIN $\%$ $\mathrm{FAT}=450-(315 \times \mathrm{R}$ value $) ;$ BELLY \% $\mathrm{FAT}=439-(298 \times \mathrm{R}$ value $)$. Bone content was calculated as described above for the total body. Lean content was calculated as: Lean $=\mathrm{CW}-($ Fat + Bone $)$, where $\mathrm{CW}$ is the carcass weight. In addition, the right half-carcass was analyzed chemically for lipid [11], protein (Kjeldahl nitrogen), water (lyophillization), and ash content (muffle furnace, $24 \mathrm{~h}$ at $500{ }^{\circ} \mathrm{C}$ ) as described by Mitchell et al. [13].

\subsection{Plasma pGH and IGF-I}

Blood was collected from the ear vein under anesthesia during the DXA scanning at 60 and $110 \mathrm{~kg} \mathrm{BW}$, and during exsanguination when the pigs were sacrificed at $120 \mathrm{~kg} \mathrm{BW}$. At the time of blood collection, all pigs had been fasted about $20 \mathrm{~h}$ at 60 and $110 \mathrm{~kg} \mathrm{BW}$ and fasted about $44 \mathrm{~h}$ when sacrificed. Blood was collected into a syringe that contained EDTA to prevent coagulation, and plasma was separated by centrifugation and stored at $-70{ }^{\circ} \mathrm{C}$ until assay. Plasma concentrations of $\mathrm{pGH}$ were determined by radioimmunoassay using guinea pig anti-porcine GH serum [23]. Plasma IGF-I was measured by double antibody radioimmunoassay using rabbit anti-human IGF-I (UBK-487, NIDDK, Bethesda, MD) as the primary antiserum and recombinant human IGF-I for standard and iodination tracer (R-D Systems, Inc., Minneapolis, MN). Samples were prepared for assay using the acid glycylglycine acidification technique [9]. The samples were all evaluated in a single assay. The intra-assay coefficient of variation was $5.8 \%$.

\subsection{Statistical analysis}

Differences in growth and body or carcass composition were analyzed by the GLM procedure of SAS (version 8.2) for a factorial design with the main treatment effects being diet, genotype and sex. Two 
and three way interactions were evaluated for each treatment combination. The experimental unit for all measures was the individual pig. SAS analysis was performed at the BARC Biometrical Consulting Service. Other statistical analysis were performed in-house using Statgraphics ${ }^{\circledR}$ Plus for Windows 2.1. Differences in plasma IGF-I and pGH and differences among gene-diet groups were analyzed by ANOVA. Chemical and DXA measurements of carcass composition were compared by $t$-test and regression analysis.

\section{RESULTS}

\subsection{Measurements of in vivo body composition at 60 and $110 \mathrm{~kg}$ body weight}

At the initial measurement at $60 \mathrm{~kg}$, the IGF-I transgenic pigs were found to have $20 \%$ less fat, $6 \%$ more lean tissue, $9 \%$ larger LEA and $16 \%$ less BF than the control pigs (Tab. II). The measurements at $110 \mathrm{~kg} \mathrm{BW}$ revealed that similar differences persisted between the TG and C pigs. At $110 \mathrm{~kg} \mathrm{BW}$, pigs fed the CLA diet had 6\% larger LEA than pigs fed the control diet. At both 60 and $110 \mathrm{~kg} \mathrm{BW}$, gilts had less fat, more lean, larger LEA, and less BF than did barrows. At $110 \mathrm{~kg}$, the gilts had less bone than did barrows. There were no gene $x$ sex or diet $x$ sex interactions. At $110 \mathrm{~kg} \mathrm{BW}$, there were significant gene $\times$ diet $\times$ sex interactions for body composition (fat and lean content, LEA, and BF).

The only gene $x$ diet interaction was for $\mathrm{BW}$ at $110 \mathrm{~kg}$. For the gene-diet groupings, at $110 \mathrm{~kg} \mathrm{BW}$ the C-CLA pigs had less fat, more lean tissue and larger LEA $(P<0.05$ for each) compared to $\mathrm{C}-\mathrm{CO}$ pigs. At $110 \mathrm{~kg} \mathrm{BW}$ no $(P>0.05)$ differences were observed between TG-C and TG-CLA pigs. At $60 \mathrm{~kg} \mathrm{BW}$, the TG-CO group had lower $(P<0.05)$ bone mass and bone density (BMD) compared to the C-CO group. At $110 \mathrm{~kg} \mathrm{BW}$, there was no $(P>0.05)$ differ- ence in total body bone mass, however, the TG-CO pigs had lower BMD than either of the control groups (C-CO and C-CLA).

\subsection{Plasma IGF-I and pGH}

The mean plasma concentrations of IGF-I and $\mathrm{GH}$ measured at $60 \mathrm{BW}, 110$ and $120 \mathrm{~kg}$ BW are shown in Figure 1. Concentrations of plasma IGF-I were higher $(P<0.05)$ in TG pigs at each time period. Overall, the level of plasma IGF-I was $21 \%$ higher $(P<0.0001)$ in the TG pigs compared to the $C$ pigs. There was no $(P>0.05)$ CLA effect on plasma IGF-I concentration; however, the levels in gilts were higher (128 ng per $\mathrm{mL}$ ) than in barrows (116 ng per $\mathrm{mL}, P=0.005)$. At $60 \mathrm{~kg} \mathrm{BW}$ there was no $(P=0.71)$ difference, but at 110 and $120 \mathrm{~kg} \mathrm{BW}$, the plasma IGF-I was $12 \%$ (129 vs. $115 \mathrm{ng}$ per $\mathrm{mL}$ ) and $15 \%$ higher (138 vs. $120 \mathrm{ng}$ per $\mathrm{mL}$ ), respectively, in gilts than in barrows $(P=0.03)$. There were no $(P>0.05)$ differences in plasma GH concentrations regardless of gender, diet or, transgene.

\subsection{Rate and composition of growth between 60 and $110 \mathrm{~kg}$ body weight}

During the period of growth from 60 to $110 \mathrm{~kg} \mathrm{BW}$, the TG pigs had a higher average daily gain (ADG) and feed efficiency $(\mathrm{G} / \mathrm{F})(P=0.002$ and $P=0.009)$, compared to the $\mathrm{C}$ pigs (Tab. III). The TG pigs deposited $2.6 \mathrm{~kg}$ less fat as the result of a $17 \%$ reduction in the rate of fat deposition. At the same time, the TG pigs had a $14 \%$ increase in the rate of lean deposition resulting in $1.6 \mathrm{~kg}$ more total body lean tissue. The combined effect was a $20 \%$ reduction in the fat:lean gain in TG pigs. The addition of CLA to the diet resulted in an overall $10 \%$ reduction in the rate of fat deposition during growth from 60 to $110 \mathrm{~kg}$. The pigs receiving CLA deposited 5\% more lean tissue. Consequently, CLA supplementation resulted in a $12 \%$ reduction in the fat:lean gain. Compared to barrows, gilts had a lower rate of fat deposition and a higher rate of lean deposition resulting in less fat and more 


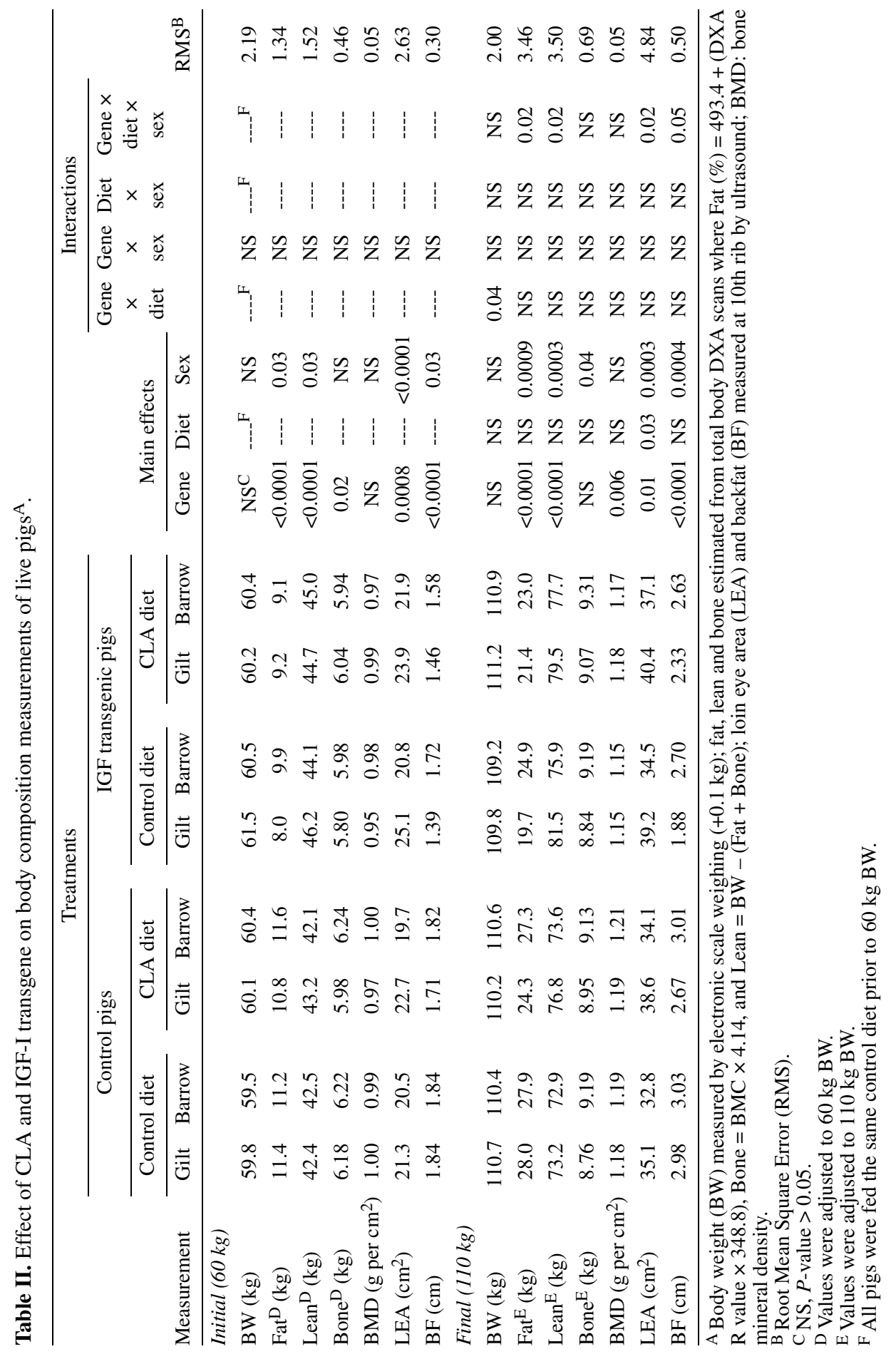




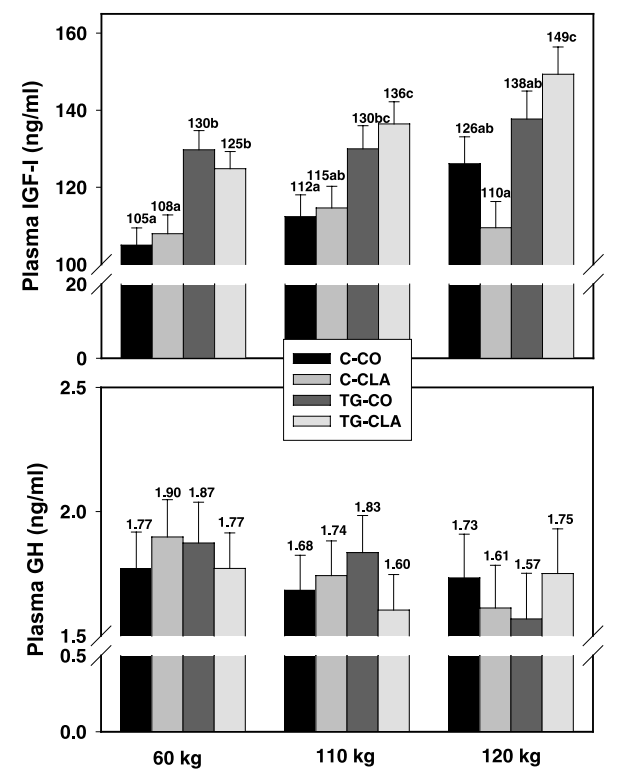

Figure 1. Least squares means of plasma concentrations of IGF-I and pGH for control (C) and transgenic (TG) pigs fed control diet (CO) or diet supplemented with conjugated linoleic acid (CLA). Blood samples from each pig were collected at 60,110 , and $120 \mathrm{~kg}$ body weight. Vertical bars are standard errors of the mean, and mean values are above each bar. Within each weight group, means followed by a different letter were significantly different $(P<0.05)$.

lean being deposited, hence a lower fat:lean gain. The TG pigs had a $19 \%$ higher rate of bone deposition. Neither diet nor sex had an effect on bone deposition and none of the treatment variables resulted in changes in total body BMD. There were no gene $x$ sex or gene $\times$ diet $\times$ sex interactions and the only diet $\times$ sex interaction was for feed intake.

Significant gene $\times$ diet interactions were noted for fat gain (fat kg per day and BF). Figure 2 shows the rates of fat, lean and bone growth that was measured in the four gene-diet groups as they grew from 60 to $110 \mathrm{~kg}$ BW. During this period, the TG-CO pigs deposited $20 \%$ less fat and $10 \%$ more lean tissue compared to their littermate controls (C) fed the $\mathrm{CO}$ diet which corresponded to a $15 \%$ lower fat and a $16 \%$ higher lean tissue deposition rate $(P<0.05)$. Pigs of the C-CLA group deposited $13 \%$ less fat than the C-CO pigs and the fat deposition rate was $15 \%$ lower $(P<0.05)$. Although the C-CLA pigs deposited $6.5 \%$ more lean, the rate of deposition was not different $(P>0.05)$ from that of the C-CO pigs. CLA did not have a significant effect on fat and lean deposition in the TG pigs.

Based on ultrasound measurements at 60 and $110 \mathrm{~kg} \mathrm{BW}$, the largest increase in LEA was in the pigs fed the CLA diets $(P=0.01)$. There was an $18 \%$ greater $(P<0.05)$ increase in LEA in C-CLA pigs and a nonsignificant $13 \%$ greater $(P>0.05)$ increase in TG-CLA pigs compared to their respective groups fed the $\mathrm{CO}$ diet. The increase in $\mathrm{BF}$ was $26 \%$ less in TG pigs compared to controls $(P=0.0004)$. The increase in $\mathrm{BF}$ was $41 \%$ less $(P<0.05)$ in the TG-CO pigs than in C-CLA pigs. There was also a smaller increase in BF in C-CLA pigs (not significant, $P>0.05$ ). However, a $35 \%$ greater $(P<0.05)$ increase in BF was measured in the TG-CLA pigs compared to the TG-CO pigs.

\subsection{DXA measurements of changes in composition of body regions}

The DXA measurements of fat, lean and bone content of each pig at 60 and $110 \mathrm{~kg}$ BW were analyzed for three major body regions: front legs, trunk and back legs. The calculated growth of each tissue component within these regions is shown in Table IV. TG pigs gained significantly less fat and more lean in all three regions. Only in the trunk region did the TG pigs have increased deposition of bone mineral (BMC). Pigs receiving CLA deposited less fat in the front and back leg regions and more lean in all three regions. Gilts gained less fat than barrows in all three regions, more lean in the trunk region, and more BMC in the back legs. There were few differences in regional bone densities (data not shown), pigs fed 
A.D. Mitchell et al.

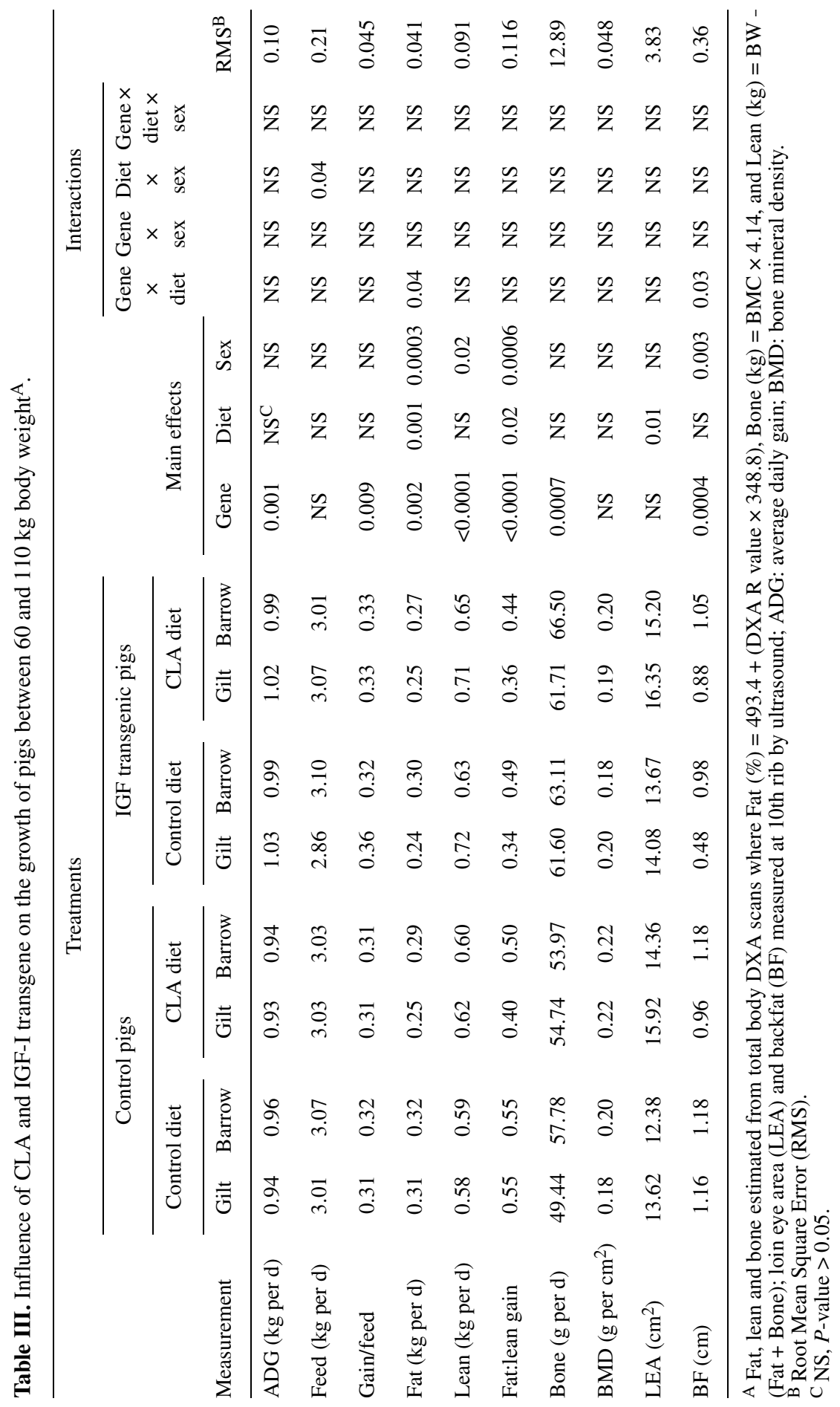




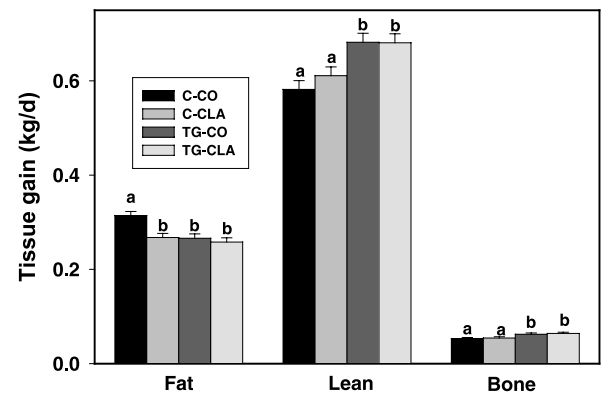

Figure 2. Fat, lean, and bone gain as measured by DXA for the period of body growth between 60 and $110 \mathrm{~kg}$ body weight in control (C) and IGF-transgenic (TG) pigs fed either the control (CO) or the CLA supplemented diet. Within each tissue type, different letters above bars indicate significant differences $(P<0.05)$.

the CLA diet had higher bone density in the front legs $(P=0.01)$ and back legs $(P=0.04)$.

The only significant interactions were for gene $x$ diet for fat and BMC gain in the trunk region. Comparing the gene-diet groups, the TG-CO pigs gained less $(P<0.05)$ fat and more $(P<0.05)$ lean in each region when compared to the $\mathrm{C}-\mathrm{CO}$ pigs. The greatest difference was in the trunk region where the TG pigs gained $41 \%$ less fat and $19 \%$ more lean $(P<0.05$ for each). Compared to C-CO pigs, pigs of the C-CLA group gained less fat and more lean in all regions, although the difference was not significant for fat growth in the trunk region and lean growth in the front leg region. The only difference in bone growth was a greater $(P<0.05)$ bone growth in the trunk region of the TG-CLA pigs compared to the other groups.

\subsection{DXA and chemical measurements of carcass composition}

The results of DXA and chemical analysis of the half-carcass of pigs slaughtered at $122 \mathrm{~kg} \mathrm{BW}$ are shown in Table V. Consistent with the live DXA measurements at $110 \mathrm{~kg} \mathrm{BW}$, DXA analysis of the carcasses of the TG pig revealed less fat and more lean than those of the control pigs. Likewise, chemical analysis found less fat, higher water content, a higher percentage of protein in the carcasses of the TG pigs compared to controls. Pigs that had received CLA had less carcass fat based on both DXA and chemical analysis. The carcasses of the gilts had less fat and more lean (protein and water by chemical analysis) than barrows by both DXA and chemical analysis. There were no gene $\times$ diet or diet $\times$ sex interactions and the only significant gene $x$ sex interaction was for carcass fat percentage by chemical analysis. Significant gene $x$ diet $x$ sex interactions were noted for DXA measured percentages of carcass fat and lean and chemical measurement of percentage of protein in the carcass.

The DXA measurements of the half-carcass by regions are shown in Table VI. The TG pigs had less fat, a lower percentage of fat, and a higher percentage of lean in all four carcass regions. Pigs fed the CLA diet had a lower percentage of fat in the shoulder and ham regions. Compared to barrows, gilts had less fat and more lean in all regions of the carcass. Barrows had more bone in the ham region, but less in the side region. There were no significant diet $\times$ sex, gene $x$ sex, or gene $\times$ diet interactions for any region. In each region there were significant gene $\times$ diet $\times$ sex interactions for the percentages of fat and lean.

A comparison of DXA and chemical analysis for measurement of composition of the half-carcass is shown in Table VII. There was good agreement between DXA and chemical determinations of carcass fat content with nearly identical mean values and high regression coefficients $\left(\mathrm{R}^{2}\right)$ for both $\mathrm{kg}$ of fat and percentage of fat. The DXA measurements of lean mass were significantly higher $(3 \%)$ than the chemical lean values calculated by combining protein and water measurements, however the $\mathrm{R}^{2}$ values were high. The DXA BMC measurement was significantly higher (17\%) 
A.D. Mitchell et al.

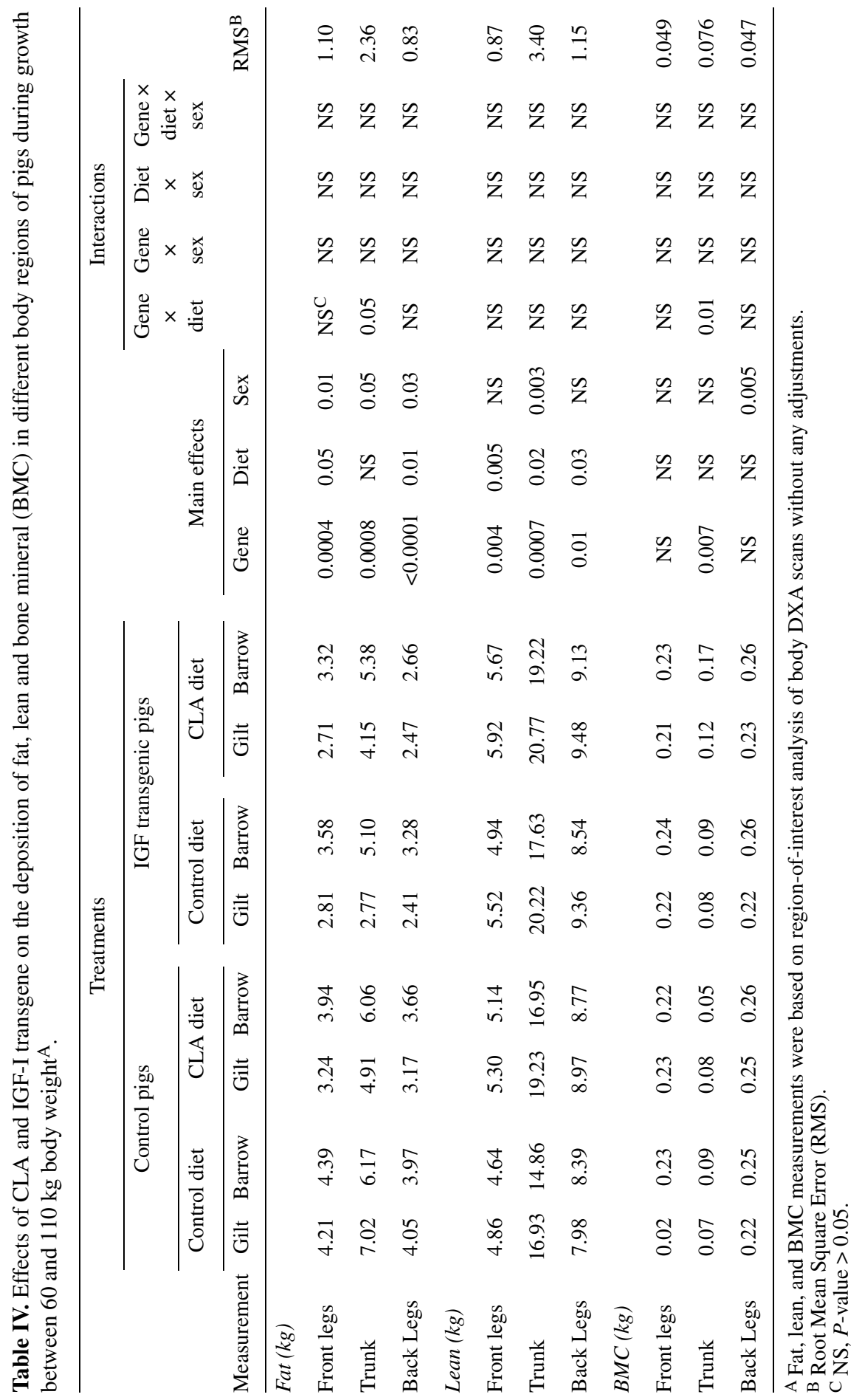




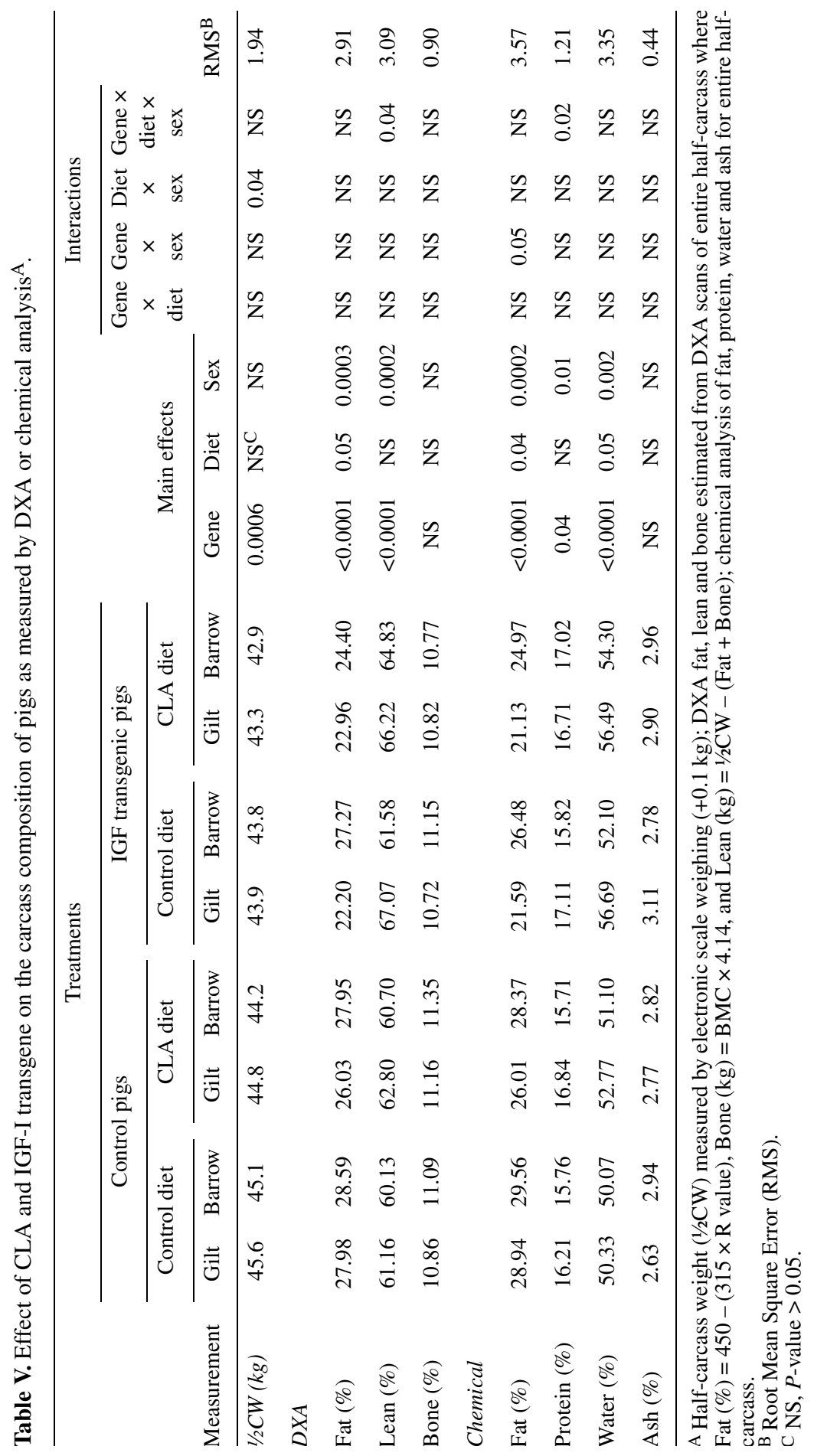


A.D. Mitchell et al.

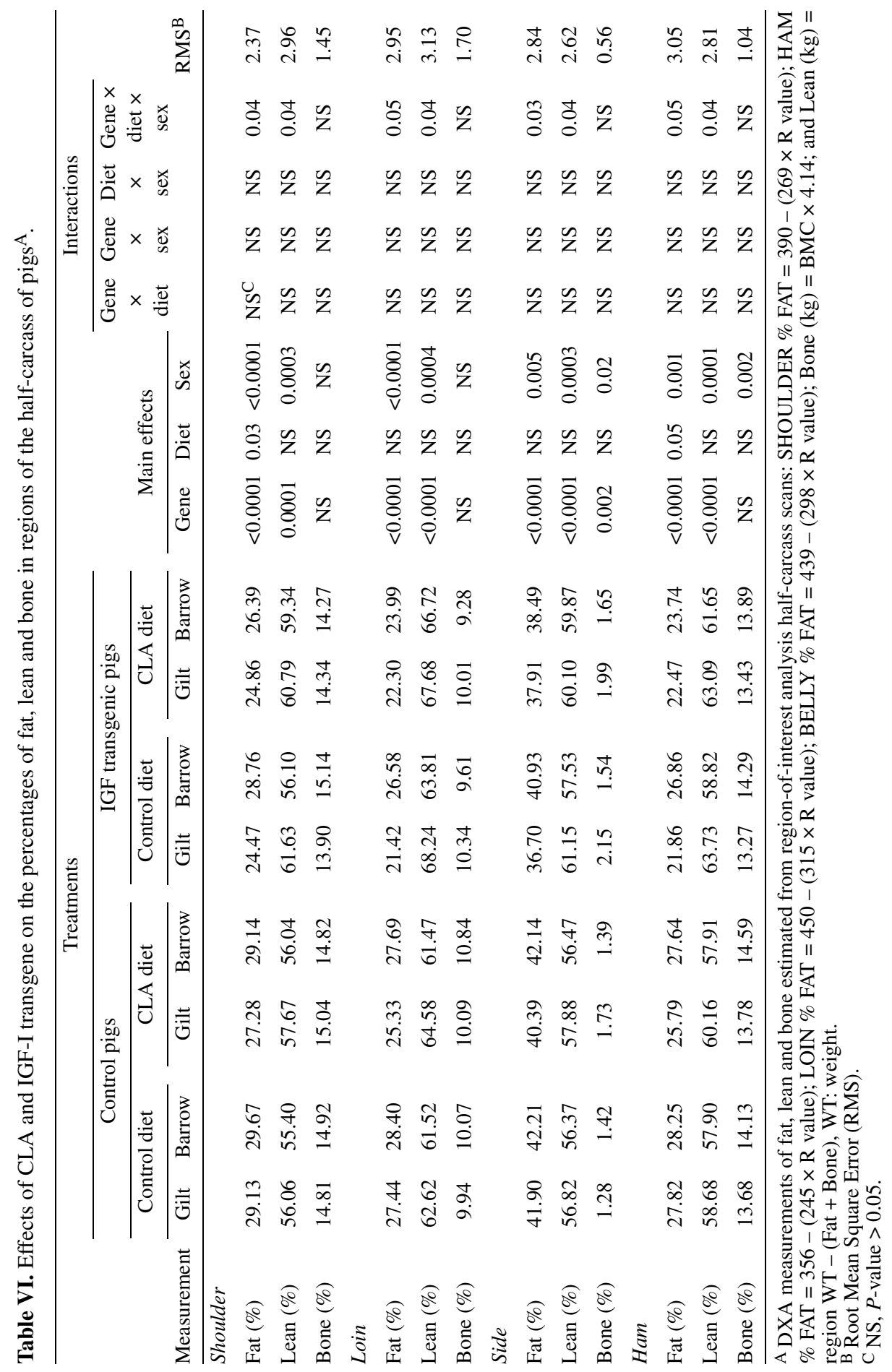


Table VII. Comparison of DXA and chemical measurements of carcass composition ( $n=97)$.

\begin{tabular}{lccccc}
\hline Measurement & $\mathrm{DXA}^{\mathrm{A}}$ & Chemical $^{\mathrm{A}}$ & $P$-value & $\mathrm{R}^{2}$ & SEE $^{\mathrm{B}}$ \\
\hline Fat $(\mathrm{kg})$ & $11.49 \pm 1.89$ & $11.47 \pm 2.26$ & 0.94 & 0.85 & 0.74 \\
Fat $(\%)$ & $25.91 \pm 3.63$ & $25.86 \pm 4.60$ & 0.94 & 0.81 & 1.57 \\
Lean $(\mathrm{kg})$ & $31.58 \pm 1.73^{\mathrm{D}}$ & $30.67 \pm 2.15^{\mathrm{E}}$ & 0.002 & 0.88 & 0.59 \\
Lean $(\%)$ & $71.44 \pm 3.67$ & $69.40 \pm 4.71$ & 0.001 & 0.86 & 1.44 \\
BMC/ash $(\mathrm{kg})$ & $1.17 \pm 0.11$ & $1.00 \pm 0.21^{\mathrm{F}}$ & $<0.0001$ & 0.11 & 0.20 \\
\hline
\end{tabular}

A DXA or chemical value \pm SD.

B $P$ value for comparison of DXA and chemical means.

C Standard error of estimate for linear regression.

D DXA lean calculated as Lean $=C W-($ DXA fat + DXA BMC $)$.

E Chemical lean calculated as Lean $=$ protein + water.

$\mathrm{F}$ Chemical bone ash values were calculated as Ash $=$ carcass ash $-($ lean mass $\times 0.0085)$.

than the chemical bone ash value (ash corrected for lean tissue mineral content) and there was a low correlation $\left(\mathrm{R}^{2}\right)$ between the two measurements. All of the chemical measurements had higher standard deviations than the DXA measurements.

\section{DISCUSSION}

The IGF-I transgenic pigs used in this study were derived from a population that has been described in previous studies [21, 22]. The differences in body composition between control and IGF-I transgenic pigs, wherein the TG pigs had less fat and more lean at both 60 and $110 \mathrm{~kg} \mathrm{BW}$, are similar to those reported previously. Consistent with the total body measurements, the TG pigs had less BF and larger LEA compared to the $\mathrm{C}$ pigs. Likewise, the plasma IGF-I concentrations observed in this study are similar to those in a previous study [21] that reported slightly higher levels in transgenic compared to non-transgenic pigs, and also, higher levels in boars compared to gilts in both non-transgenic and transgenic pigs. As with the previous study, there was no difference in the level of plasma $\mathrm{GH}$ between the TG and $\mathrm{C}$ pigs, indicating that the slight elevation in circulating IGF-I was not enough to suppress plasma GH in the TG pigs. The TG pigs had a higher ADG and feed efficiency compared to the $\mathrm{C}$ pigs during the growth period from 60 to $110 \mathrm{~kg}$ $\mathrm{BW}$. This is in contrast to the lack of an effect of the IGF transgene on the rate of gain and feed efficiency of gilts and boars reported in previous studies [21, 22]. Perhaps contributing to the improvement in growth performance was the significant increase in lean tissue deposition in the TG pigs compared to $\mathrm{C}$ pigs that was not observed in the prior studies.

\subsection{Effects of CLA}

The addition of CLA to the diet did not affect either ADG or feed efficiency. The lack of an effect of CLA on ADG is in agreement with other studies, however the same studies reported an increase in G/F [6, 19, 20, 29, 30]. The improvement in feed efficiency has been attributed to a decrease in feed intake [20]. No differences in feed intake were observed in the present study, however it should be noted that all pigs were fed at $110 \%$ of calculated ad libitum intake rather than true ad libitum. The primary effects of CLA that were observed in this study were a lower rate of fat deposition and a lower fat:lean gain during the period of growth between 60 and $110 \mathrm{~kg} \mathrm{BW}$. The reduction in fat deposition resulted in less fat in the carcass, but no difference in the 
DXA measurement of total body fat or the ultrasound measured $\mathrm{BF}$ at $110 \mathrm{~kg} \mathrm{BW}$. Numerous other studies have reported that feeding CLA to swine resulted in a reduction in BF $[3,5,6,28-30]$ or fat mass [6, $19,20,27]$. The only indications of increased lean as the result of CLA were a larger LEA (live ultrasound at $110 \mathrm{~kg} \mathrm{BW}$ ) and a higher percentage of water in the carcass (chemical measurement). Based on DXA measurements, CLA did not result in an increase in either total body lean mass at $110 \mathrm{~kg} \mathrm{BW}$ or carcass lean mass. In contrast, several studies reported that CLA resulted in an increase in lean mass or lean deposition [3, $5,19,20,27]$. There was no effect of CLA on bone deposition or bone density. In the study by Ostrowska et al. [20], DXA measurements of both the live animals and carcasses showed no effect of CLA on either bone growth or BMD. Other studies report no effect of dietary CLA supplementation on carcass ash content [19] or dissected bone weight [5].

\subsection{Interactions}

The main objective of this study was to compare the response of control and IGF-I transgenic pigs to dietary CLA. Significant diet $\times$ gene interactions were observed for the rate of fat deposition and total backfat deposition during growth from 60 to $110 \mathrm{~kg}$ BW. CLA (C-CLA) and the IGF-I transgene (TG-CO) resulted in the same level of reduction in the rate of fat deposition relative to control pigs (C-CO), however CLA did not lower the rate of fat deposition in TG pigs (TG-CLA). Backfat deposition was reduced by the IGF-I transgene but not by CLA, in fact, backfat deposition was greater in the TG-CLA pigs compared to TG-CO pigs. The reason for the observed greater increase in $\mathrm{BF}$ in the TG-CLA pigs compared to the TG-C pigs is not known and is not supported by the DXA measurements of gain in either the percentage or amount of fat gained during growth from 60 to $110 \mathrm{~kg} \mathrm{BW}$. The results of the DXA measurements showing that control pigs fed the CLA diet had less fat and more lean than those fed the CO diet, are consistent with those of Ostrowska et al. [20]. Control pigs fed the CLA diet also had less carcass fat than those fed the $\mathrm{CO}$ diet, but only the results based on chemical analysis were statistically significant. Likewise, Ostrowska et al. [20] observed differences in chemical carcass composition, but not DXA carcass composition of control and CLA supplemented pigs. At $110 \mathrm{~kg} \mathrm{BW} \mathrm{no}$ differences in body composition were observed between TG-C and TG-CLA pigs, nor were there any differences in carcass composition between the two groups. These results indicate that the IGF-I transgenic pigs were less responsive to CLA than were their littermate controls. In the case of lean pigs, like the TG pigs in this study, it may be that CLA will not cause a further decrease in fat deposition, which is in line with previous reports $[2,8]$. In contrast, CLA was reported to decrease backfat depth in lean contemporary genotypes housed under commercial conditions [6] and in stressgenotype pigs [29]. The ratio of fat-to-lean gain ranged from 0.40 for the TG-CLA pigs to 0.55 for $\mathrm{C}-\mathrm{CO}$ pigs. For the control pigs in this study, the rates of fat deposition (267-314 g per day) and lean deposition (586-611 g per day) were comparable to those based on DXA measurements in the study reported by Ostrowska et al. [20] (249-334 and 467-556 g per day, respectively).

Various studies concerning the effects of CLA on the carcass composition of pigs have included measurements of the change in composition of specific body regions. With DXA total body scans, body region analysis is important because it allows the trunk region, that includes the viscera and other non-carcass components, to be analyzed separately from the limbs. In the present study, it was noted that both the live animal and carcass measurements by DXA indicated that the TG pigs less fat and more lean than control pigs in each region, whereas, the pigs fed the CLA diet had less fat in the shoulder and ham regions and more lean in each region compared to pigs 
on the control diet. Dunshea et al. [6] noted that dietary CLA decreased the rate of accumulation of fat in the shoulder, particularly of gilts, resulting in a significantly lower amount of shoulder fat at slaughter. The study by Dugan et al. [5] reported less subcutaneous fat in all carcass regions (picnic, butt, loin and ham) of pigs that had been fed CLA. Swan et al. [26] measured a higher percentage of moisture and protein and a decreased percentage of lipids in the bellies of pigs fed a CLA-supplemented diet. A significant diet $\times$ gene interaction for fat deposition in the trunk region indicates that the IGF-I transgene reduced fat deposition in that region, whereas there was a tendency for CLA to reduce fat deposition in trunk of control pigs, but to increase fat deposition in the TG pigs. Based on DXA live animal measurements, the TG pigs deposited more bone mineral in the trunk region. The DXA region measurements found no differences in bone content between pigs fed the CLA and control diets. Thiel-Cooper et al. [28] reported a dose dependent linear increase in dissected bone in the loin of pigs fed CLA, however, other studies report no effect of CLA on bone content of the loin [5] or the carcass $[5,19,20]$.

In comparing the relative effects of CLA and the IGF-I transgene on the growth and carcass composition of pigs, the IGF-I transgene resulted in an increase in both growth rate and the efficiency of feed utilization, whereas CLA did neither. Both DXA and chemical analysis showed that the carcass of the TG-CO pigs contained less fat than that of the C-CLA pigs. The carcasses of TG pigs also had a higher percentage of lean (DXA) and a higher water content (chemical), however, there was no difference in bone (DXA), protein or ash (chemical) content. It has not been established at what point during growth, expression of the IGF-I transgene first becomes evident, however by $60 \mathrm{~kg}$ BW differences in body composition are significant as demonstrated in the present and in previous studies [21, 22]. Thus, the TG pigs already had an advantage in terms of improved body composition at the time that the CLA feeding was started $(60 \mathrm{~kg} \mathrm{BW})$. By comparing the response of the C-CLA pigs to the TG-CO pigs during the treatment period from 60 to $110 \mathrm{~kg} \mathrm{BW}$, it appears that the effects of CLA and the IGF-I transgene on the composition of growth were similar, with only a more rapid rate of lean deposition and less BF deposition occurring in the TG pigs compared to controls fed CLA.

\subsection{The use of DXA to measure body and carcass composition}

In addition to comparing the effects of CLA and the IGF-I transgene, this study demonstrates that one of the main benefits of DXA is the ability to evaluate the composition of growth of each individual within the timeframe of a specific treatment. Within the relatively narrow window of growth between 60 and $110 \mathrm{~kg}$, the beginning composition of the pig can influence its final composition. Thus, the measurements of the composition of growth (Tab. III) are a better indicator of the effects of CLA than either the final live animal (Tab. II) or carcass (Tab. V) measurements. Validation studies have indicated that DXA is a potentially accurate and reliable method for estimating both live animal and carcass composition of swine [13, 17, 24, 26]. In the present study the comparison of DXA and chemical measurements of carcass composition confirm the accuracy of prediction equations for estimating the fat content of the carcass. The small but significant differences in estimation of lean and bone content suggest that additional refinement is needed for these measurements. The low correlation between DXA BMC and bone ash can be attributed in part to the difficulty in obtaining reliable ash values from ground carcass samples [17].

\section{CONCLUSIONS}

Overall, the effects of CLA were less than those of IGF-I transgene on body or 
carcass composition; however, the main advantage of the IGF-transgene was realized prior to $60 \mathrm{~kg} \mathrm{BW}$. Thus, during the treatment period from 60 to $110 \mathrm{~kg} \mathrm{BW}$, the effects were similar, with only a more rapid rate of lean deposition and less BF deposition observed in the TG pigs compared to controls fed CLA. TG pigs did not respond to CLA as much as did control pigs, resulting in no difference in final body or carcass composition for TG pigs fed the CO or CLA diets.

In addition to the effects of the IGF-I transgene and CLA supplementation, the results of this study indicate that for final carcass evaluation, DXA was somewhat less sensitive than chemical measurements. However, the end point measurements provided by either DXA or chemical analysis were not as useful in assessing treatment response as were the comparative DXA "growth" measurements based on live total body scans at 60 and $110 \mathrm{~kg} \mathrm{BW}$.

\section{REFERENCES}

[1] ARC, The Nutrient Requirements of Pigs, Agricultural Research Council, Commonwealth Agricultural Bureaux, Slough, UK, 1981, p. 307.

[2] Bee G., Dietary conjugated linoleic acids affect tissue lipid composition but not de novo lipogenesis in finishing pigs, Anim. Res. 50 (2001) 1-17.

[3] Dugan M.E.R., Aalhus J.L., Lien K.A., Schaefer A.L., Kramer J.K.G., Effects of feeding different levels of conjugated linoleic acid and total oil to pigs on live animal performance and carcass composition, Can. J. Anim. Sci. 81 (2001) 505-510.

[4] Dugan M.E., Aalhus J.L., Kramer J.K., Conjugated linoleic acid pork research, Am. J. Clin. Nutr. 79 (Suppl. 6) (2004) 1212S$1216 \mathrm{~S}$.

[5] Dugan M.E.R., Aalhus J.L., Schaefer A.L., Kramer J.K.G., The effect of conjugated linoleic acid on fat to lean partitioning and feed conversion in pigs, Can. J. Anim. Sci. 77 (1997) 723-725.

[6] Dunshea F.R., Ostrowska E., Luxford B., Smits R.J., Campbell R.G., D’Souza D.N., Mullan B.P., Conjugated linoleic acid can decrease backfat in pigs housed under commercial conditions, Asian-Aust. J. Anim. Sci. 15 (2002) 1011-1017.

[7] Dunshea F.R., Suster D., Kerton D.J., Leury B.J., Exogenous porcine somatotropin administered to neonatal pigs at high doses can alter lifetime fat but not lean tissue deposition, Brit. J. Nutr. 89 (2003) 795-801.

[8] Eggert J.M., Belury M.A., Kempa-Steczko A., Mills S.E., Schimckel A.P., Effects of conjugated linoleic acid on the belly firmness and fatty acid composition of genetically lean pigs, J. Anim. Sci. 79 (2001) 2866-2872.

[9] Elsasser T.H., Rumsey T.S., Hammond A.C., Fayer R.J., Influence of parasitism on plasma concentrations of growth hormone, somatomedin-C and somatomedin-binding proteins in calves, J. Endocrinol. 116 (1988) 191-200.

[10] Field R.A., Riley M.L., Mello F.C., Corbridge M.H., Kotula A.W., Bone composition in cattle, pigs, sheep and poultry, J. Anim. Sci. 39 (1974) 493-499.

[11] Folch J., Lees M., Sloane Stanley G.H., A simple method for the isolation and purification of total lipids from animal tissue, J. Biol. Chem. 226 (1957) 497-509.

[12] McCauley I., Watt M., Suster D., Kerton D.J., Oliver W.T., Harrell R.J., Dunshea F.R., A GnRF vaccine (Improvac ${ }^{\circledR}$ ) and porcine somatotropin (Reporcin $\AA$ ) have synergistic effects upon growth performance in both boars and gilts, Aust. J. Agric. Res. 54 (2003) 21-26.

[13] Mitchell A.D., Conway J.M., Potts W.J.E., Body composition analysis of pigs by dualenergy X-ray absorptiometry, J. Anim. Sci. 74 (1996) 2663-2671.

[14] Mitchell A.D., Conway J.M., Scholz A.M., Incremental changes in total and regional body composition of growing pigs measured by dual-energy X-ray absorptiometry, Growth Develop. Aging 60 (1996) 113-123.

[15] Mitchell A.D., Scholz A.M., Pursel V.G., Dual energy X-ray absorptiometry measurements of the body composition of pigs of 90to 130-kilograms body weight, Ann. N.Y. Acad. Sci. 904 (2000) 85-93.

[16] Mitchell A.D., Scholz A.M., Pursel V.G., Total body and regional measurements of bone mineral content and bone mineral density in pigs by dual energy X-ray absorptiometry, J. Anim. Sci. 79 (2001) 2594-2604.

[17] Mitchell A.D., Scholz A.M., Pursel V.G., Evock-Clover C.M., Composition analysis of pork carcasses by dual-energy X-ray absorptiometry, J. Anim. Sci. 76 (1998) 2104-2114. 
[18] Oliver W. T., McCauley I., Harrell R J., Suster D., Kerton D.J., Dunshea F.R., A gonadotropin-releasing factor vaccine (Improvac) and porcine somatotropin have synergistic and additive effects on growth performance in group-housed boars and gilts, J. Anim. Sci. 81 (2003) 1959-1966.

[19] Ostrowska E., Muralitharan M., Cross R.F., Bauman D.E., Dunshea F.R., Dietary conjugated linoleic acids increase lean tissue and decrease fat deposition in growing pigs, J. Nutr. 129 (1999) 2037-2042.

[20] Ostrowska E., Suster D., Muralitharan M., Cross R.F., Leury B.J., Bauman D.E., Dunshea F.R., Conjugated linoleic acid decreases fat accretion in pigs: evaluation by dual-energy X-ray absorptiometry, Brit. J. Nutr. 89 (2003) 219-229.

[21] Pursel V.G., Mitchell A.D., Bee G., Elsasser T.H., McMurtry J.P., Wall R.J., Coleman M.E., Schwartz R.J., Growth and tissue accretion rates of swine expressing an insulin-like growth factor I transgene, Anim. Biotechnol. 15 (2004) 33-45.

[22] Pursel V.G., Wall R.J., Mitchell A.D., Elsasser T.H., Solomon M.B., Coleman M.E., DeMayo F., Schwartz R.J., Expression of insulin-like growth factor-I in skeletal muscle of transgenic swine, in: Murray J.D., Anderson G.B., Oberbauer A.M., McGloughlin M.M. (Eds.), Transgenic Animals in Agriculture, $\mathrm{CAB}$ International, 1999, pp. 131-144.

[23] Steele N.C., McMurtry J.P., Rosebrough R.W., Endocrine adaptations of periparturient swine to alteration of dietary energy source, $\mathrm{J}$. Anim. Sci. 60 (1985) 1260-1271.

[24] Suster D., Leury B.J., Hofmeyr C.D., D’ Souza D.N., Dunshea F.R., The accuracy of dual energy X-ray absorptiometry (DXA), weight, and $\mathrm{P} 2$ back fat to predict half-carcass and pri- mal-cut composition in pigs within and across research experiments, Aust. J. Agric. Res. 55 (2004) 973-982.

[25] Suster D., Leury B.J., King R.H., Mottram M., Dunshea F.R., Interrelationships between porcine somatotropin (pST), betaine, and energy level on body composition and tissue distribution of finisher boars, Aust. J. Agric. Res. 55 (2004) 983-990.

[26] Suster D., Leury B.J., Hofmeyr C.D., D'Souza D.N., Dunshea F.R., Accuracy of dual energy $\mathrm{X}$-ray absorptiometry (DXA), weight, and P2 back fat to predict whole body and carcass composition in pigs within and across experiments, Livest. Prod. Sci. 84 (2003) 231-242.

[27] Swan J.E., Parrish F.C. Jr., Wiegand B.R., Larsen S.T., Baas T.J., Berg E.P., Total body electrical conductivity (TOBEC) measurement of compositional differences in hams, loins, and bellies from conjugated linoleic acid (CLA)-fed stress-genotype pigs, J. Anim. Sci. 79 (2001) 1475-1482.

[28] Thiel-Cooper R.L., Parrish F.C. Jr., Sparks J.C., Wiegand B.R., Ewan R.C., Conjugated linoleic acid changes swine performance and carcass composition, J. Anim. Sci. 79 (2001) $1821-1828$.

[29] Wiegand B.R., Parrish F.C. Jr., Swan J.E., Larson S.T., Baas T.J., Conjugated linoleic acid improves feed efficiency, decreases subcutaneous fat, and improves certain aspects of meat quality in Stress-Genotype pigs, J. Anim. Sci. 79 (2001) 2187-2195.

[30] Wiegand B.R., Sparks J.C., Parrish F.C. Jr., Zimmerman D.R., Duration of feeding conjugated linoleic acid influences growth performance, carcass traits, and meat quality of finishing barrows, J. Anim. Sci. 80 (2002) 637-643. 